\title{
The Role of Macroeconomic Factors as Moderating the Global Sharia Stock Index to the Indonesian Sharia Stock Index
}

\author{
Abid Djazuli ${ }^{1}$, Dinarossi Utami ${ }^{2}$, Mister Candera ${ }^{3}$ \\ ${ }^{1,2,3}$ Fakultas Ekonomi dan Bisnis, Universitas Muhammadiyah Palembang
}

\begin{abstract}
This study examined the influence of the global sharia stock index on the Indonesian sharia stock index considering macroeconomic factors and their moderating role. The Global sharia Stock Index in this study used the Dow Jones sharia Market Index and the FTSE Global sharia Index Series. The role of moderation is proxied by inflation rate and exchange rate. The research data analysis method used multiple regression analysis and interaction test or moderating regression analysis. The results of the study showed that there was an influence of the Global Sharia Stock Index on the Indonesian Sharia Stock Index. In the moderation equation 1 (inflation) and moderation 2 (exchange rate) that interact with the Dow Jones sharia Market Index has a positive influence on each moderation equation. This showed that a moderating interaction with the Dow Jones sharia Market Index will strengthen its influence on the Indonesian Sharia Stock Index. The FTSE Global sharia Index Series that interacted with inflation in moderating equation 1 and the exchange rate in moderating equation 2 showed a negative effect. This showed that the interaction of the FTSE Global sharia Index Series with the two macroeconomic variables in each equation weakens its influence on the Indonesian Sharia Stock Index.
\end{abstract}

KEYWORD: The Global Sharia Stock Index, The Indonesian Sharia Stock Index, Inflation, Exchange Rate

\section{INTRODUCTION}

Capital market as an important role in the economy of a country. The capital market acts as an important link between savers and investors. Capital markets mobilize savings and distribute them into productive investments for the development of trade and industry. Several efforts have been made to improve the quality of a country economy by developing the investment sector through the capital market, including the sharia capital market in Indonesia.

The sharia capital market in Indonesia was inaugurated on March 14, 2003 with the signing of a Memorandum of Understanding (MoU) between Capital Market and Financial Institution Supervisory Agency
(Bapepam-LK) and the Indonesian Ulema Council (Djamil, 2008). In fact, sharia investment activities have already started. The sharia capital market activities are not different from conventional capital markets, but sharia capital markets have products and transaction mechanisms that are in line with sharia principles.

The Indonesian Sharia Stock Index (ISSI) is an indicator of sharia stocks performance in Indonesia. The Indonesian Sharia Stock Index (ISSI) was inaugurated on May 12, 2011 that is a composite index of sharia stocks listed on the Indonesia Stock Exchange. The following is the growth of Indonesian sharia stock.

Figure 1. The Growth of Sharia Stock in Indonesian

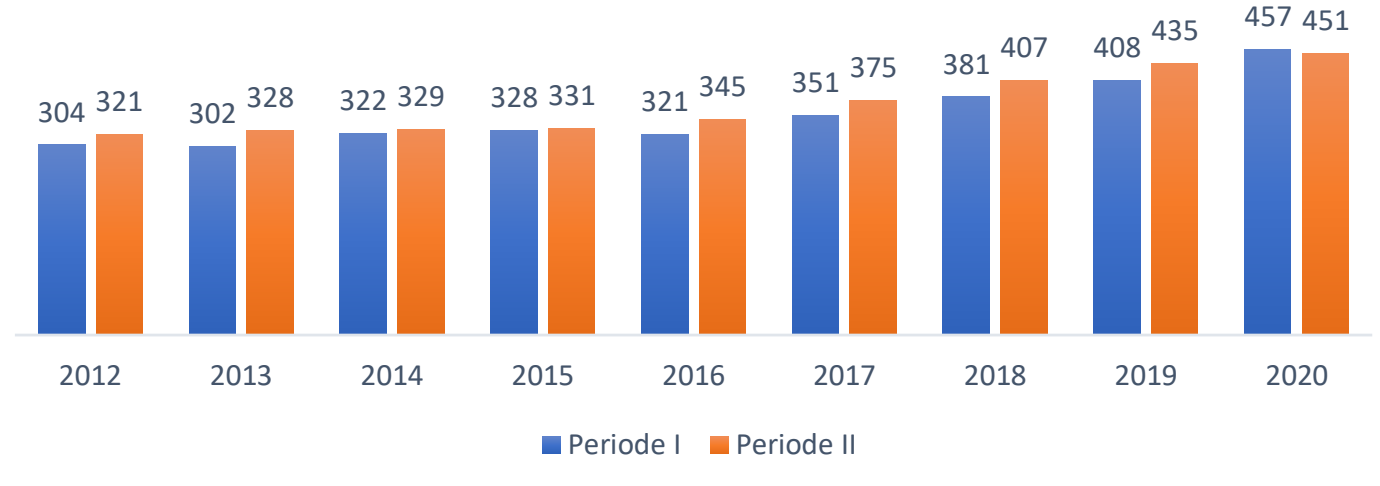

Source: Processed Secondary Data, 2021 
Based on the figure above, it can be seen that the Indonesia sharia stock is growing every year. There is a reduction in the amount of the period within the year due to the screening process carried out regularly by the Indonesia Stock Exchange so that the listed shares have met the sharia criteria.

The economy between one country and another is interrelated through trade and investment activities. So that the information and macroeconomic conditions of other countries will have impact on interrelated country. The Indonesian stock exchange is also an inseparable part of the activities of the global stock exchange. Some indices such as the Dow Jones Index are an index on the United States stock exchange that is used by almost all financial or fund managers in Asia Pacific as a trading standard. Therefore, any changes that occur in the Dow Jones index, especially the Dow Jones sharia Market Index (DJIMI) will affect stock prices in Indonesia (Riantani, 2013). In addition, there is the Financial Times Stock Exchange Global sharia Index Series (FTSE GIIS) index that is also one of the global indices in this study.

The relationship between the global Islamic stock index and the Indonesian Islamic stock index is based on the Contagion Effect Theory that is an increase in cross-market relationships after an incident in one or a group of countries (Nurbaya, 2020). Various studies have been conducted to see how the global sharia stock index influences the Indonesian sharia stock index Azzis (2017), Triana (2019), Ardana (2019), Kurniawan, (2019), Kusnita (2020). In addition, several studies were also conducted with an inter-country scope (Antonio, 2013; Case 2018); Chavali 2020; Gok, 2018; Irfan 2016)

This study examined the effect of the global Islamic stock index on the Indonesian Islamic stock index. In addition, this study also considers macroeconomic factors such as inflation and exchange rates and their moderating role on the global sharia stock index in forming the Indonesian sharia stock index so that it can provide a clear illustration related to several policies in the Islamic finance field.

\section{RESEARCH METHODOLOGY}

This type of research was associative research aimed to determine the effect of the Global Sharia Index on the Indonesian Sharia Stock Index, by examining the role of macroeconomic factors as moderating variables. The Indonesian Sharia Stock Index is an indicator of the performance of the Indonesian Islamic stock market. The Global Sharia Stock Index in this study used the Dow Jones sharia Market Index (DJIMI) and the FTSE Global sharia Index Series (GIIS). The researcher used the two indexes because they are considered to be an appropriate index by looking at the history of the emergence of the global sharia index. The macroeconomic variables that become the moderating variables were the inflation rate and the exchange rate of the Rupiah against the Dollar.

\section{RESULTS}

The results of the study will explain the description of the research data and the results of the regression estimation of each equation. An explanation of the main variables used in the study can illustrate the representation of the sample used.

The following is a statistical Table for each research variables used in the basic regression.

Table 1. Descriptive Statistics

\begin{tabular}{lllll}
\hline Variable & Average & $\begin{array}{c}\text { Std. } \\
\text { Dev. }\end{array}$ & Maximum & Minimum \\
\hline Ln_ISSI & 8.044 & 0.219 & 8.603 & 7.634 \\
Ln_DJI & & & & \\
MI & 7.647 & 0.151 & 8.206 & 7.328 \\
Ln_GIIS & 5.096 & 0.112 & 5.286 & 4.853 \\
\hline
\end{tabular}

Source: Processed Secondary Data, 2021

Based on the statistical table of 108 observations, the Average value was Ln_ISSI; Ln_DJIMI; and Ln_FTSE were 8,044 respectively; 7,647; and 5,096. The higher the value of the index number indicates that the more market movements occur, the increasing number and size of transactions carried out (tanusdjaja, 2019).

Before estimating the regression, the step was to test the database so that the equations in the regression did not experience multicollinearity problems. The following is a paired correlation matrix table:

Table 2. Pairwise Correlation Matrix

\begin{tabular}{lll}
\hline Variable & Ln_DJIMI & Ln_FTSE \\
\hline Ln_DJIMI & 1.00 & 0.57 \\
Ln_GIIS & 0.57 & 1.00 \\
VIF $=1.492187$ &
\end{tabular}

Source: Processed Secondary Data, 2021 


\section{Index"}

The results in the paired correlation matrix table showed that the coefficient value between the independent variables was 0.57 . If the coefficient value between independent variables does not exceed 0.8 , then there is no multicollinearity problem (Kuncoro, 2014). In addition, the Variance Inflation Factor (VIF) test is also carried out to show how the variance of an estimator is increased through the presence of multicollinearity. The higher the VIF value, the more collinear a Variable will be. Several textbooks explain that the tolerance limit for the VIF value is 10 (Fitriya fauzi,
2019). The VIF value between the variables in this study was 1.492187, so it can be concluded that there was no multicollinearity problem in this study.

\section{Estimation of Basic Equation}

After multicollinearity test, the next step is to estimate. The results of the estimation of the basic equations of the study using the Ordinary Least Square method as shown in the following table:

Table 3. Results of Basic Equation Estimation

\begin{tabular}{lllll}
\hline Variable & Coefficient & Std. Error & t-Statistic & Prob. \\
\hline C & -2.499035 & 0.326788 & -7.647259 & 0.000000 \\
Ln_DJIMI & 1.426654 & 0.048619 & 29.343290 & 0.000000 \\
Ln_GIIS & -0.072006 & 0.065217 & -1.104099 & 0.272100 \\
& & & \\
R-squared & 0.921413 & Mean dependent var & 8.043796 \\
Adjusted R-squared & 0.919917 & S.D. dependent var & 0.218976 \\
S.E. of regression & 0.061968 & Akaike info criterion & -2.69702 \\
Sum squared resid & 0.403203 & Schwarz criterion & -2.62251 \\
Log likelihood & 148.638800 & Hannan-Quinn criter. & -2.66681 \\
F-statistic & 615.553000 & Durbin-Watson stat & 1.170475 \\
Prob(F-statistic) & 0.000000 & & \\
Sourc: Processed & &
\end{tabular}

Source: Processed Secondary Data, 2021

Based on the estimation table, the following equation can be obtained:

Ln_ISSI $=-2.499035+1.426654$ Ln_DJIMI 0.072006 Ln_GIIS $+\varepsilon$

\section{Estimation of Moderation Equation}

The model estimation carried out by considering macroeconomic variables as moderating variables and their moderating role on the Global Sharia Stock Index in forming Indonesian Sharia Stock Index. There are two moderating variables in the study that will be estimated respectively. The following are the results of the estimation of the research moderation equation

Table 4. The Results of Moderation I Equation

\begin{tabular}{lllll}
\hline Variable & Coefficient & Std. Error & t-Statistic & Prob. \\
\hline C & -0.330456 & 0.010682 & -30.9350 & 0.000000 \\
Ln_DJIMI & 1.041064 & 0.001889 & 551.0850 & 0.000000 \\
Ln_GIIS & 0.002253 & 0.002118 & 1.063724 & 0.290000 \\
INF & 0.006453 & 0.001423 & 4.534278 & 0.000000 \\
Ln_DJIMI*INF & 8.213250 & 0.022775 & 360.6215 & 0.000000 \\
Ln_GIIS*INF & -8.222489 & 0.022997 & -357.5439 & 0.000000 \\
& & & \\
R-squared & 0.999956 & Mean dependent var & 8.043796 \\
Adjusted R-squared & 0.999954 & S.D. dependent var & 0.218976 \\
S.E. of regression & 0.001492 & Akaike info criterion & -10.12321 \\
Sum squared resid & 0.000227 & Schwarz criterion & -9.974200 \\
Log likelihood & 552.6532 & Hannan-Quinn criter. & -10.06279 \\
F-statistic & 460833.8 & Durbin-Watson stat & 0.578243 \\
Prob(F-statistic) & 0.000000 & \multicolumn{2}{l}{} \\
\hline
\end{tabular}

Source: Processed Secondary Data, 2021 
In Table 4, the estimation results of the moderating equation showed that there was a significant effect of inflation as a moderating variable on the Dow Jones sharia Market Index
(DJIMI) and the FTSE Global sharia Index Series (GIIS) on the Indonesian Sharia Stock Index.

Table 5. The Results of Moderation 2 Equation

\begin{tabular}{lllll}
\hline Variable & Coefficient & Std. Error & t-Statistic & Prob. \\
\hline C & -0.359003 & 0.212191 & -1.691885 & 0.093700 \\
Ln_DJIMI & 1.088036 & 0.028676 & 37.94185 & 0.000000 \\
Ln_GIIS & 0.001974 & 0.000482 & 4.098324 & 0.000100 \\
KURS & 0.036449 & 0.022298 & 1.634642 & 0.105200 \\
Ln_DJIMI*KURS & 0.104295 & 0.000084 & 1249.470 & 0.000000 \\
Ln_GIIS*KURS & -0.113480 & 0.003036 & -37.38335 & 0.000000 \\
& & & \\
R-squared & 0.999997 & Mean dependent var & 8.043796 \\
Adjusted R-squared & 0.999996 & S.D. dependent var & 0.218976 \\
S.E. of regression & 0.000412 & Akaike info criterion & -12.69623 \\
Sum squared resid & 0.000017 & Schwarz criterion & -12.54722 \\
Log likelihood & 691.5965 & Hannan-Quinn criter. & -12.63582 \\
F-statistic & 6039663 & Durbin-Watson stat & 1.116397 \\
Prob(F-statistic) & 0.000000 & & \\
Source: Processed Secondary & Data, 2021 & &
\end{tabular}

In Table 2, the estimation results of the moderating equation showed that there was a significant effect of the exchange rate as a moderating variable on the Dow Jones sharia Market Index (DJIMI) and the FTSE Global sharia Index Series (GIIS) on the Indonesian Sharia Stock Index.

\section{DISCUSSION}

The Influence of the Global Sharia Stock Index on Indonesian Sharia Stock Index (Basic Equation)

Based on the estimation results, the first equation showed that there is an influence of the Global Sharia Stock Index on the Indonesian Sharia Stock Index. Rsquared value is a measurement to assess how much the independent variable can explain the dependent variable. The Rsquared value of this study was 0.921413 , it means that all of the Global Sharia Stock Index Variables, namely the Dow Jones sharia Market Index (DJIMI) and the FTSE Global sharia Index Series (GIIS) were able to explain the Indonesian Sharia Stock Index Variables of $92.14 \%$ and $7.86 \%$. explained by other variables outside the study.

The results of the individual regression estimates showed that the Dow Jones sharia Market Index (DJIMI) had a positive and significant effect on the Indonesian Sharia Stock Index with a coefficient of 1.426654. It means that if the Dow Jones sharia Market Index (DJIMI) increases by $1 \%$, the Indonesian Sharia Stock Index will increase by 1.426654 , and vice versa. The existence of a positive relationship between the Dow Jones sharia Market Index (DJIMI) and the Indonesian Sharia Stock Index showed that the first hypothesis of the study was accepted. In addition, the results of the study are also in accordance with the concept of Contaigon theory, namely an increase in cross-market relations in a country (Nurbaya, 2020). There is market tie that causes mutual influence between several countries.

The regression estimation results also show that the FTSE Global sharia Index Series (GIIS) had no a significant effect on the Indonesian Sharia Stock Index. In addition, the results of the study showed that there was a negative relationship between the FTSE Global sharia Index Series (GIIS) and the Indonesian Sharia Stock Index. The lack of influence is due to the fact that cooperation in the field of Islamic finance, including the Islamic capital market between Indonesia and the UK, was planned for 2015 and in 2012 the UK experienced a financial crisis. The results of this study are also in line with research conducted by Neni (2019).

\section{The Influence of the Dow Jones sharia Market Index} (DJIMI) on Indonesian Sharia Stock Index

The estimation results of basic equation, moderation equation 1 and moderation 2 showed that the Dow Jones sharia Market Index (DJIMI) had a significant influence on the Indonesian Sharia Stock Index. The three estimation results also show a positive influence with each coefficient of 1.426654 in the basic equation, 1.041064 in the moderating equation 1 , and 1.088036 in the moderating equation 2 . It showed that if there is an increase of one percent in the Dow Jones sharia Market Index (DJIMI) then there is an increase in the Indonesian Sharia Stock Index of each coefficient.

Several factors influenced the stock index of a country such as macroeconomic factors, one of which is the 
state of the index of other countries. As we know that the Dow Jones sharia Market Index (DJIMI) is part of the global Dow Jones index (DJGI) consists of stocks from 34 countries and covers 10 economic sectors, 18 market sectors, 51 groups, and 89 sub-industrial groups based on standards. Dow Jones Global classification. The Dow Jones sharia Market Index (DJIMI) did not include overall index of any industry group that represents a mismatch with the line of business based on Islamic principles. Therefore, an increase in the Dow Jones sharia Market Index (DJIMI) will have a positive effect on increasing the Indonesian Sharia Stock Index (Kurniawan, 2019).

The Influence of the FTSE Global sharia Index Series (GIIS) on the Indonesian Sharia Stock Index

The estimation results of the basic equation, moderation equation 1 and moderation 2 showed that the FTSE Global sharia Index Series (GIIS) had a significant influence on the Indonesian Sharia Stock Index. In the basic equation, the magnitude of the coefficient was 0.072006 with a negative direction. Meanwhile, in the moderation equation 1 and moderation equation 2 , the coefficients were 0.002253 and 0.001974 , respectively, in a positive direction. This showed that if there is a one percent change in the FTSE Global sharia Index Series, there will be a change in the Indonesian Sharia Stock Index for each coefficient.

The Global sharia Index Series that is part of the FTSE world index group, involves stocks from 29 countries. The FTSE also had 15 stock indexes where the classification is based on industry (10 indices) and region (global, America, Europe, Pacific Basin, South Africa). The collaboration between the UK and Indonesia in the field of Islamic finance is only planned for 2015, therefore some research results show that there was no effect of the FTSE Global sharia Index Series on the Indonesian Sharia Stock Index (Triana, 2019). However, in this research period, from January 2012 to December 2020, it showed that there is an effect of the FTSE Global sharia Index Series on the Indonesian Sharia Stock Index and supports the research conducted by Azzis (2017).

\section{The Influence of Inflation on the Indonesian Sharia Stock} Index

The estimation results on inflation towards the Indonesian Sharia Stock Index (ISSI) in the second equation of the study showed that inflation had a significant positive effect on the Indonesian Sharia Stock Index (ISSI). It showed that if there is a change in inflation, it will affect the Indonesian Sharia Stock Index (ISSI) during the study period, namely January 2012 to December 2020. If inflation increases by one percent, it will increase the Indonesian Sharia Stock Index by 0.006453 percent.

The existence of inflation that is an increase in the price of goods continuously causes a decrease in the purchasing power of the people. The decrease in people purchasing power affects the level of product sales at the company so that the company's profitability decreases. If there is a decrease in the company's profitability, it will reduce the demand for investors to invest. Investors will consider delaying investing in the capital market. However, in the period of this study, inflation did not reduce investor interest as seen in the Indonesian Sharia Stock Index (ISSI). This implies that inflation is not the main constraint in investing compared to the level of trust in companies seen in the Indonesian Sharia Stock Index. This study supports the statement of research conducted by Rakasetya et al (2013).

\section{The Influence of Exchange Rate on Indonesian Sharia} Stock Index

The estimation results on the exchange rate of the Indonesian Sharia Stock Index (ISSI) in the third equation of the study showed that the exchange rate had a significant positive effect on the Indonesian Sharia Stock Index (ISSI). It showed that if there is a change in the exchange rate, it will affect the Indonesian Sharia Stock Index (ISSI) during the study period, namely January 2012 to December 2020. If the exchange rate increases by one percent, it will increase the Indonesian Sharia Stock Index by 0.104295 percent. The results of this study are in line with research conducted by Isnaini (2013), Nofianti (2013).

Several studies had differences in research results where there was no effect of the exchange rate on the stock index (Hismendi, 2013). If the rupiah weakens against the dollar, it will affect companies that have debt in the form of dollars or companies that import so that it will reduce the company's income. The decrease of income will affect investors in investing capital. Vice versa, if the exchange rate of the rupiah against the dollar has increased, it will affect the increase in company income.

\section{Influence of Dow Jones sharia Market Index (DJIMI) on Indonesian Sharia Stock Index Moderated by Inflation}

Based on the estimation of equation 1, inflation is a moderating variable of the influence of the Dow Jones sharia Market Index (DJIMI) on the Indonesian Sharia Stock Index. From the estimation results of moderating equation 1 , it showed that the interaction effect of the relationship between the Dow Jones sharia Market Index (DJIMI) and inflation was positive and significant with a coefficient value of 8.213250 and a probability of 0.000000 . This implies that inflation strengthens the influence of the Dow Jones sharia Market Index (DJIMI) on the Indonesian Sharia Stock Index.

\section{Influence of FTSE Global sharia Index Series (GIIS) on Indonesian Sharia Stock Index Moderated by Inflation}

Equation 1 showed that inflation is a moderating variable of the influence of the FTSE Global sharia Index Series (GIIS) on the Indonesian Sharia Stock Index. From the estimation results of moderating equation 1 , it showed that the interaction effect of the relationship between the FTSE Global sharia Index Series (GIIS) and inflation is negative 
and significant with a coefficient value of 8.222489 and a probability of 0.000000 . This implies that inflation weakens the influence of the FTSE Global sharia Index Series (GIIS) on the Indonesian Sharia Stock Index.

Inflation is a condition of the increase in prices that occurs continuously and widely (Suciningtyas, 2015). The existence of a positive or negative impact from the interaction of inflation depends on the economy of a country. Fluctuations in the inflation rate in Indonesia will certainly affect the level of investment that occurs in the Indonesian capital market as is the case with the Indonesian Sharia Stock Index (ISSI).

The Influence of the Dow Jones sharia Market Index (DJIMI) on the Indonesian Sharia Stock Index Moderated by Exchange Rates

Based on the estimation of equation 2, it showed that the Exchange Rate is a moderating variable of the influence of the Dow Jones sharia Market Index (DJIMI) on the Indonesian Sharia Stock Index. From the estimation results of moderating equation 2 , it showed that the interaction effect of the relationship between the Dow Jones sharia Market Index (DJIMI) and the Exchange Rate was positive and significant with a coefficient value of 0.104295 and a probability of 0.000000. It implies that the Exchange Rate strengthens the influence of the Dow Jones sharia Market Index (DJIMI) on the Indonesian Sharia Stock Index.

The Influence of the FTSE Global sharia Index Series (GIIS) on the Indonesian Sharia Stock Index Moderated by Exchange Rates

The results of the study based on the estimation of equation 2 showed that the Exchange Rate that is a moderating variable of the influence of the FTSE Global sharia Index Series (GIIS) on the Indonesian Sharia Stock Index. From the estimation results of moderating equation 2, it showed that the interaction effect of the relationship between the FTSE Global sharia Index Series (GIIS) and the Exchange Rate was negative and significant with a coefficient value of 0.113480 and a probability of 0.000000 . It implies that the Exchange Rate weakens the influence of the FTSE Global sharia Index Series (GIIS) on the Indonesian Sharia Stock Index.

The exchange rate will affect the course of a country economic activities, especially the relationship between exports and imports. If there is a strengthening of foreign currency against Indonesia, it will benefit companies that export from Indonesia, and vice versa. For companies in the Indonesian capital market, trade transactions also use exchange rates in their trading activities. Therefore, the exchange rate is very capable of influencing changes in the index as happened in the Indonesian Sharia Stock Index.
Based on the test results of the basic equation, the moderating equation 1 and the moderating equation 2 showed that there was an influence of the Global Sharia Stock Index proxied by the Variable Dow Jones sharia Market Index (DJIMI) and the FTSE Global sharia Index Series (GIIS) on the Indonesian Sharia Stock Index. Moderation equation 1 (inflation) and moderation 2 (exchange rate) interacted with the Dow Jones sharia Market Index (DJIMI) which had a positive effect on each moderation equation. It showed that the interaction of the Dow Jones sharia Market Index (DJIMI) with inflation and the exchange rate will strengthen its influence on the Indonesian Sharia Stock Index. Meanwhile, the Variable FTSE Global sharia Index Series (GIIS) which interacts with inflation in moderating equation 1 and the exchange rate in moderating equation 2 showed a negative effect. It also shows that the interaction of the FTSE Global sharia Index Series (GIIS) with the two macroeconomic variables in each equation weakens its influence on the Indonesian Sharia Stock Index.

This study examined the theoretical relationship between the Global Sharia Stock Index and the Indonesian Sharia Stock Index by considering macroeconomic variables such as inflation and exchange rates that may affect the relationship. It can have important policy implications because it will have a direct or indirect impact on the capital market index especially the Indonesian Sharia Stock Index.

This study had several limitations that only considers two Global Sharia Stock Indexes and focuses on the interaction of two macroeconomic variables, as well as the short time span of the study. Therefore, suggestions for further researchers to consider the addition of macroeconomic variables and developing other index measures so that the findings become more comprehensive.

\section{REFERENCE}

1. Antonio, Muhammad Syafii, Hafidhoh dan Hilman Fauzi. (2013). The Islamic Capital Market Volatility: A Comparative Study Between In Indonesia And Malaysia. Bulletin of Monetary, Economics and Banking.

2. Ardana, Yudhisitira dan Siska Maya (2019). Determinasi Faktor Fundamental Makroekonomi dan Indeks Harga Saham Syariah Internasional terhadap Indeks Harga Saham Syariah Indonesia. Jurnal Studi Islam,Vol. 14 No. 1: pp. 1-15.

3. Azzis, Abdul (2017). Analisis Pengaruh Variabel Makro ekonomi dan Indeks Saham Syariah Regional terhadap Risiko Jakarta Islamic Index (JII). Universitas Islam Negeri Syarif Hudayatullah Jakarta.

4. Case, B. (2018). Stock Market Reaction to Monetary Policy : An Event Study Analysis of the Stock Market Reaction to Monetary Policy : An Event Study Analysis of the Brazilian Case. Emerging 
Markets Finance and Trade,54(11), 2577-2595. https://doi.org/10.1080/1540496X.2017.1364622.

5. Chavali, K., Alam, M. N., \& Rosario, S. (2020). Stock Market Response to Elections: An Event Study Method Stock Market Response to Elections : An Event Study Method. 7(June). https://doi.org/10.13106/jafeb.2020.vol7.no5.009

6. Djamil, F. (2008). Prospek Pasar Modal Syariah Indonesia. Nationalon Performance and Prospect of Indonesian Islamic Capital Market Conference. Jakarta: STIE Ahmad Dahlan.

7. Gok, I. Y., \& Dayi, F. (2018). The Effects of Political Uncertainty on the Turkish Stock Market: An Event Study Analysis. March. https://doi.org/10.31410/EMAN.2018.191

8. Hismendi, Abubakar Hamzah dan Said Musnadi. (2013). Analisis Pengaruh Nilai Tukar, SBI,Inflasi dan Pertumbuhan GDP Terhadap Pergerakan Indeks Harga Saham Gabungan di Bursa Efek Indonesia. Jurnal Ilmu Ekonomi Pascasarjana Universitas Syiah Kuala. Vol. 1, No.2, 16-28.

9. Irfan, M. (2016). A Study of Islamic Stock Indices and Macroeconomic Variables. International Journal of Social, Behavioral, Educational, Economic, Business and Industrial Engineering, 10(7), 2557-2565.

10. Isnaini, Nor dan Nunung Ghoniyah. (2013). Analisis Risiko Investasi Saham pada Perusahaan yang Go Publik di Jakarta Isamic Index (JII). Media Ekonomi dan Mnajeman. Vol. 28, No 2

11. Kurniawan Agus, Fahri Alia dan Meli Apriyani. (2019). Pengaruh Dow Jones Islamic World Malaysia Index dan Dow Jones Islamic Market Japan Index Terhadap Indeks Saham Syariah Indonesia (Periode Januari 2013-Desember 2017).
Jurnal Akuntansi dan Perbankan Syariah,Vol. 02 No. 01, Januari-Juni 2019.

12. Kusnita Lisa dan Andrianna Syarieful Rakhmat (2020). Bursa Saham Syariah Global dan Indeks Harga Saham Syariah. Jurnal Ilmiah Manajemen dan Bisnis, Vol. 21 No. 1, April: 20-27.

13. Nofianti, Ike. 2013. Hubungan Inflasi, Suku Bunga, Produk Domestik Bruto, Nilai Tukar, Jumlah Uang Beredar, dan Indeks Harga Saham Gabungan Periode 2005 - 2011. Jurnal Aplikasi Manajeman. Vol. 11 No,2.

14. Nurbaya, Siti (2020). Manajemen Sumber Daya Manusia Di Era Revolusi Industri 4.0.Makasar: Nas Media Pustaka.

15. Rakasetya, Gadang Ganggas, Darminto dan Moch Dzulkiron. (2013). Pengaruh Faktor Mikro dan Faktor Makro Ekonomi Terhadap Harga Saham Perusahaan Mining And Mining Services yang Terdaftar di Bursa Efek Indonesia. Jurnal Administrasi Bisnis. Vol. 6 No. 2.

16. Riantani, Suskim dan Maria Tambunan (2013). Analisis Pengaruh Variabel Makroekonomi dan Indeks Global terhadap Return Saham. Semantik: Universitas Widyatama Bandung.

17. Suciningtias, Siti Aisiyah dan Rizki Khoiroh. 2015. Analisis Dampak Variabel Makro Ekonomi Terhadap Indeks Saham Syariah Indonesia (ISSI). $2^{\text {nd }}$ Conference in Business, Accounting, and Management. Vol.2 No.1. May 2015.

18. Triana, Neni (2019). Hubungan Kausalitas Antara Indeks Harga Saham syariah Di Negara Malaysia, Singapura Dan Indek sharga Saham Syariah jakarta Islamic Index (JII) Di indonesia. Iltizam Journal Of Shariah Economic Research, Vol. 3, No. 2. 